\title{
Internet Kiosks in Rural India: What Influences Success? ${ }^{\#}$
}

\author{
Jake Kendall ${ }^{\dagger}$ \\ Nirvikar Singh ${ }^{\ddagger}$
}

January 2007

(Revised)

\begin{abstract}
In this paper we investigate an example of a very widely applied model for the delivery of IT services to rural and poor populations. The model is one where limited intervention to support infrastructure and coordinate resources is combined with marketbased delivery of IT services to the end user (what we call here the "sustainable franchise model”). Though this model has been deployed world-wide by governments, NGOs, and development institutions in the past few years, there has been little research into the determinants of success in such a model. In this paper we examine the example of nLogue, a franchise of over 1000 locally-owned, Internet kiosks in rural villages in India. We seek to assess how this new sustainable franchise model has worked in practice by analyzing data from 74 of n-Logue’s kiosks. Among other things, we find that gender and education do not affect success, while location and other measures of social standing (age and caste) do. We also find that the uses that villagers have for IT services are not so different from those which first world users have. The lessons we draw from this example are that while local customs and practices must be taken into account (e.g. the caste system), it is not a foregone conclusion that social biases (e.g. against women) cannot be mitigated by good program design.
\end{abstract}

\footnotetext{
\# The second author is grateful to the UCSC Academic Senate, Rajiv Gandhi Institute for Contemporary Studies, and International Development Enterprises (India) for financial support. Both authors are grateful to the NET Institute for their generous support of this project. We would like to thank Rob Fairlie, Lauren Malone, and the participants of the UC Santa Cruz Economics Department seminar for detailed comments and suggestions.

${ }^{\dagger}$ Department of Economics, University of California, Santa Cruz, Santa Cruz, CA 95064, USA, jkendall@ucsc.edu

${ }_{\ddagger}$ Department of Economics and Santa Cruz Center for International Economics, University of California, Santa Cruz, Santa Cruz, CA 95064, USA, boxjenk@ucsc.edu, 831-459-4093
} 


\section{Introduction}

There has been a debate in the press and in policy circles (e.g. Hammond 2001, New York Times 2000) over whether advanced communication and information technologies (abbreviated IT or ICT) have a useful place in development policy. There has been a corresponding debate in the academic economic literature as to what effect these technologies have on productivity, and hence growth, in general. ${ }^{1}$ For the most part the results of these parallel debates indicate that IT can have a positive effect on productivity and growth, and that it can be a useful tool of development policy. ${ }^{2}$ IT and the Internet are never the sole answer, of course; the side of the IT skeptics has been summarized by the pithy observation that "you can't eat computers" (from Steinberg, 2003). Nevertheless, there are many situations where IT can deliver real benefits and cost savings either as an alternative, or as a complement to physical infrastructure development.

\section{Sustainable Franchise Model}

In this paper we take the benefits from IT as a given. Thus, our goal is not to examine the overall case for IT investment. The main question, from our perspective, is how to deliver IT-enabled services cheaply and effectively at the village level? Simultaneously, one must ask which services are the right ones. To sort through these types of issues, many who worry about development have adopted the concept of "sustainability" as a useful benchmark. In essence, the principle of sustainability states

\footnotetext{
${ }^{1}$ Much of the debate has focused on the United States, with Jorgenson (2001) and Stiroh (2002) finding positive productivity impacts of IT, while Baily (2004) and Gordon (2004) offer cautionary conclusions. The consensus seems to have shifted toward accepting that IT has had measurable positive effects on productivity. For developed countries more generally, several recent studies have also found positive impacts at the aggregate level (e.g., Daveri, 2000), Jorgenson, 2004). Micro-level studies for developed countries also tend to find positive productivity impacts of IT use, when appropriate organizational changes are introduced as well (e.g., Bresnahan, Brynjolfsson and Hitt, 2002; Brynjolfsson and Hitt, 2003; Black and Lynch, 2004; OECD, 2004). For developing countries, there is little econometric evidence at the microlevel, and aggregate evidence is more mixed (e.g., Dewan and Kraemer, 2000), but overall, positive impacts of IT seem to be emerging from many studies (e.g., Indjikian and Siegal, 2005).

${ }^{2}$ Secretary-General Kofi Annan stated in his Millennium Report, "New technology offers an unprecedented chance for developing countries to 'leapfrog' earlier stages of development. Everything must be done to maximize their peoples' access to new information networks." (United Nations, 2001)
} 
that development efforts should be economically or commercially self-sustaining eventually, and that preferably they should be made sustainable through some kind of market mechanism. Generally, this line of thinking leads to the conclusion that IT should be promoted with as limited an intervention as possible to overcome barriers that were keeping a market from developing on its own. This approach clearly meets some objections of skeptics who would argue that IT investment takes away resources from direct interventions in areas such as health and education.

In this paper we investigate an example of a very widely applied model for the delivery of IT services to rural and poor populations. The model is one where limited intervention to support infrastructure and coordinate resources is combined with marketbased delivery of services to the end user. We will call this the "sustainable franchise model” since the case that we study is one of a franchise system in rural India. Though not always conceived of directly as a franchise there have been a large number of similar projects worldwide where village-level entrepreneurs are engaged to deliver IT-enabled services with some potential for them to capture part of the profits. Generally, the model is one of government, NGO, or multilateral intervention at the top to support infrastructure and organizational development, transitioning to greater entrepreneurial activity and market mediation at the point where services are delivered to end users. This model has the nice feature that it will fail (or adapt) relatively quickly if it provides services that end users do not consider valuable enough to pay for. It also has the potential to become fully self-sustaining in the long run as a system of for-profit small businesses.

The broad idea of user charges or user fees has been put forward (e.g., World Bank, 2003) as a way to avoid over-subscription of primary services that are supplied by governments and public entities in developing countries. The concept is controversial and has been criticized for discouraging (on the margin) the poorest from seeking needed medical, educational, and nutritional support (e.g., World Bank 2002). The idea of having self-funding programs that impose some willingness-to-pay requirement on the end user echoes some of the principles of the sustainable franchise model. The two concepts are 
quite different, however. While a system based on user charges does incorporate some price-like features, it is typically discussed in the context of public provision, and hence does not feature the main driving force of efficiency in the market, which is the profit motive. It is often the lack of incentives among public employees actually responsible for delivering services that creates inefficiencies in delivery and wastes resources (e.g., World Bank, 2006, Chapter 2). In some cases then - though clearly not those where extreme deprivation is the primary concern - the self-sustaining franchise model may be a useful complement or alternative to public provision with user charges.

Though the sustainable franchise model has been deployed in many parts of the world in the past few years, there has been little empirical study of the determinants of its success. In this paper we take a look at the example of n-Logue, a franchise of over 1000 locally-owned, Internet kiosks in villages in India. We seek to assess how this new sustainable franchise model has worked in practice, by analyzing data from 74 of nLogue’s kiosks.

Ours is one of the first papers to use a panel data set of individual firms in a rural village environment to address the topic of what factors drive firm success. The question of what factors affect the success of the individual kiosks is very relevant to discussions of the sustainability of efforts by governments and aid organizations when trying to extend similar programs to other parts of India and across the developing world. We can address this question directly with our data. We also discuss the likely effects on the village and on the individuals involved in running the kiosks. As a new economic opportunity and profit making activity, these kiosks have the potential to accelerate development. They can also serve to increase the level of entrepreneurial and technical skill in the local economy, and generally can lower transaction costs for many activities. Additionally, our data indicates that women and individuals with no formal college education suffer no disadvantage when running a kiosk, which leads us to the conclusion that the kiosks may have a positive impact on social and economic equality as well. Finally, we have limited data on the uses that rural village customers have made for the Internet. Among the most common uses are email, chat and other communications, online 
learning, as well as online match-making, horoscopes, and games. Interestingly, these are also some of the major uses that first world consumers have for the Internet, an observation that we pass on to the reader without much comment except to note that these revealed preferences may not match what centralized policy makers or humanitarian academics would choose for rural populations.

This paper is structured as follows. In the next section, we provide a limited survey of similar IT delivery programs worldwide and compare them to the n-Logue corporation, in order to give a sense of the range of implementations of these programs. In section 3, we describe the data and the empirical methods we use. The data comes from southern and western India, and provides information on characteristics and performance of individual Internet kiosks supported by n-Logue. In section 4, we describe our results, which suggest that some socio-economic characteristics of kiosk operators matter for performance, while others do not. In addition, some characteristics of the kiosks themselves matter more than others. In the final section we attempt to synthesize conclusions from our results and make them relevant to other IT-based efforts world-wide.

\section{Franchise Models for IT-Enabled Service Delivery}

n-Logue is a private "quasi-non-profit" corporation which provides telecommunications infrastructure, and a combination of hardware, software and training for turnkey operation of rural Internet kiosks. While n-Logue itself is registered as a corporation under the Indian Companies Act, its majority ownership lies with a nonprofit corporation (Vishal Bharat Comnet). This corporation, in turn, has ties with a research group at the Indian Institute of Technology (IIT), Madras. The IIT researchers have provided many of the technology tools used in the kiosks. At various times, n-Logue has also collaborated with state and local governments, the MIT Media Lab, and agroprocessing and financial corporations to set up and run the kiosks, and to deliver various services. This loose affiliation of government, academic, and private sector to start the project and support it from above is closer to a fully private enterprise than some of the 
other examples of IT delivery programs from other parts of the world mentioned later in this section. This type of collaboration can work in India due to its well developed academic and technical institutions and its high level of technical sophistication.

Currently, n-Logue is involved in over 1000 rural Internet kiosks, primarily in southern and western India. In managing this network, n-Logue uses a tiered franchise model, in which geographic clusters of kiosks are sometimes assigned under contract to a "local service partner" (LSP), which engages in ongoing management of the kiosks. In some cases, n-Logue plays this role itself. Kiosk owners themselves operate under a franchise arrangement, paying fixed fees for the equipment, maintenance and training required, but keeping all marginal revenues. N-Logue is the largest of several organizations implementing this model in rural India. ${ }^{3}$

The technology used by n-Logue is a combination of off-the-shelf components and hardware and software developed in conjunction with IIT, Madras. The franchisees receive training and equipment from n-Logue and contract with the area LSP in order to have voice and Internet connectivity via a wireless base-station. The equipment is typically one computer with microphone and video capabilities along with a receiver to connect to the wireless base-station. Given the unreliability of electric power supplies throughout India, UPS units and battery backups have been essential equipment for all kiosks. Kiosks now also typically include peripherals such as printers, webcams and digital cameras. The wireless base-stations are used in rural regions where laying long cables would be prohibitively expensive. They provide medium-speed upload and download and simultaneous telephone services. They involve tall towers with $25 \mathrm{~km}$ line-of-sight range. The technology is, in many respects, not state-of-the-art, but it is adapted to function reasonably well in village India. ${ }^{4}$

\footnotetext{
${ }^{3}$ ITC, an India-based agribusiness multinational, has more kiosks, but uses a very different organizational structure. It does not charge its operators, and even gives them commissions on crop procurement through its kiosks, implicitly making money through resulting cost savings in its supply chain. Drishtee has a similar structure to n-Logue, but is somewhat smaller in scope and operations. See Singh (2004) and Dossani et al (2005) for more details on various Indian cases.

${ }^{4}$ See Paul (2004), Dossani et al (2005) and Singh (2006) for more discussion of and information on the technologies used in n-Logue and similar cases. There is a useful subsidiary point to be made here, that the fall in costs of ICT components has allowed a substantial degree of technological leapfrogging by
} 
A number of sources document programs with similar structures to n-Logue in India and other parts of the world. ${ }^{5}$ We briefly describe three of these programs, to give an idea of the geographic range and scope of implementation of entrepreneurial models of IT delivery built on a foundation of social goals. ${ }^{6}$

The Grameen Bank was an early leader in promoting the sustainable franchise model. One very successful program to deliver technology to the rural poor is the Grameen Village Phone initiative which gives loans to by cell phones to small-scale entrepreneurs in areas that have limited or no access to ground lines. Here again, the intervention is top down, providing limited training, awareness, commercial partnerships, and - most importantly in this case - financing, while the entrepreneurs at the village level pursue profits. The program is active in a number of countries including Uganda, Cameroon, the Philippines, Bangladesh, and India.

In Peru, the cabinas públicas are small local Internet cafes that are run as forprofit enterprises delivering no-frills Internet and telephone services to local residents. Credit for the cabinas públicas phenomenon is often given to José Soriano, a Peruvian journalist. He founded RCP (Red Cientifica Peruana - The Scientific Network of Peru), which then founded the first ISP in Peru. Initially, RCP offered free classes in the start-up and management of a cabinas públicas encouraging anyone to start one. This is in contrast to the franchise model employed by n-Logue in that there are no franchise fees or any direct relationship between RCP and the cabinas públicas. The model is obviously sustainable as all elements are for-profit except for the initial intervention by RCP to educate and create awareness of the opportunity. While this more free-form model has its advantages there is the drawback that without an organized franchise, the competition has been very stiff as many cabinas públicas crowd into smaller and smaller territories.

developing countries. Perhaps the most striking example of this is the common use of mobile phones by developing country populations that have never had fixed-line access.

${ }^{5}$ See Kovacs (2004), Best and Maclay (2002), Intel (2006)

${ }^{6}$ For other examples from around the globe, including non-entrepreneurial models, see Hawkins (2002), McNamara (2003), and Tongia et al (2005). 
In Hungary, the system of teleház (telecommunications houses) offers similar services to the previous examples (phone and Internet mostly) but are run on a slightly different model. The teleház is officially owned by a local non-profit or civic institution and supported by the local government which provides a building. The operator is free to make profits in a variety of ways but is also required to provide some services for the public good. The system of teleház features a greater degree of intervention and local government control than many other programs but still retains the important feature that the local entrepreneur receives profit from the kiosk. This example and the Peruvian one show how the level of government involvement can vary greatly depending on the goals of the program and the local situation.

The list of similar programs goes on and on. Though they often differ in the details, the common framework involves some non-market intervention by the government, NGO, or multilateral development institution at an organizational and infrastructure level to "prime the pump" for local entrepreneurs and businesses that deploy services to the end user. The intervention often occurs at a higher level and serves as much to motivate and empower the local entrepreneur as it does to attract larger corporate entities. Often, the private sector has to be educated to the fact that there may be profit-potential from selling equipment and services to the smaller, more fragmented rural IT market. Often no direct subsides are needed, only impetus and coordination.

While many of these programs are described in glowing terms by those who create and promote ICT based development, some are more successful than others. There is an art to the design of such programs. It is very difficult to know beforehand how much intervention will be necessary and how exactly to design the program to recruit, train, and support the entrepreneurs. We hope this study will add to the body of knowledge that is relevant for such decision making and program design. 


\section{Data and Empirical Strategy}

We have obtained six consecutive months of data on kiosk performance for 74 kiosks, covering the period April 2004 to September 2004. These kiosks were distributed across 4 states in southern and western India, as indicated in Figure 1. As illustrated in the figure, the bulk of the kiosks were in the southernmost state of Tamil Nadu. Basic economic characteristics of the four states are presented in Table 1. All four states are at least somewhat above the nationwide average in income, urbanization and literacy, and have poverty rates lower than the all-India average. Tamil Nadu stands out among the four in being the most densely populated of the four states. Of course, within each state there is considerable variation.

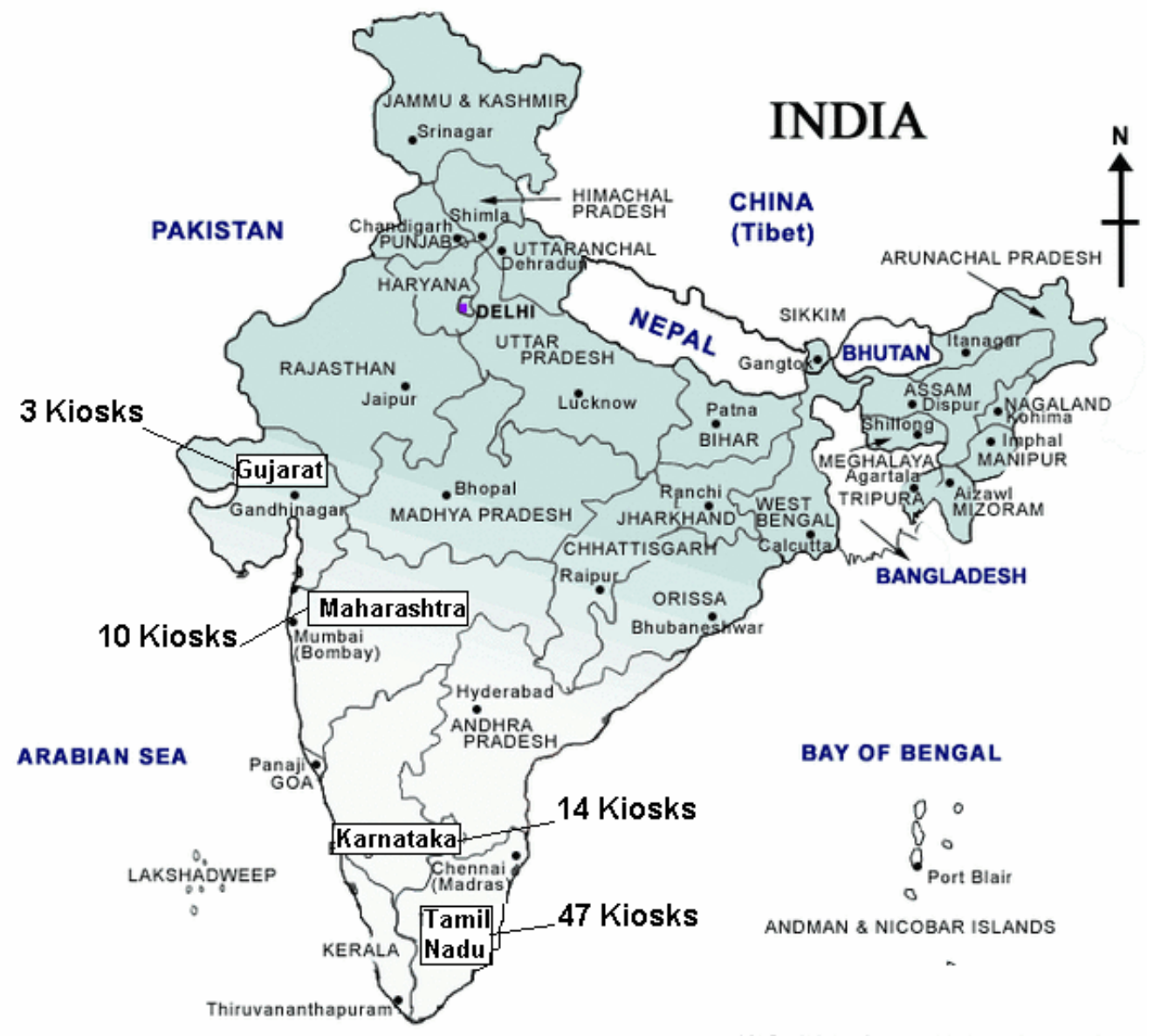

Figure 1 Location of Sample Kiosks 


\section{Data Characteristics}

The nature of the data collected is as follows. We have monthly data on total revenue, as well as on the number and types of services offered by each kiosk. ${ }^{7}$ The kinds of services offered are summarized in Table 2. Note that several of the services use IT capabilities without requiring the Internet; computer games also feature prominently. Very broadly, the purposes served by the use of IT include information gathering, document preparation, entertainment, and general communication or information exchange. Given the universality of these needs, it is not surprising that the range of services is not that different from what is popular in developed countries at higher income levels - there are no doubt differences in sophistication and intensity of use that come with greater wealth, but even relatively poor and uneducated people find that ICTs are useful.

Table 1: Economic Characteristics of Sample States

\begin{tabular}{l|cccccc} 
& $\begin{array}{c}\text { Population 2001 } \\
\text { (million) }\end{array}$ & $\begin{array}{c}\text { Area 2001 } \\
\text { ('000 sq. km.) }\end{array}$ & $\begin{array}{c}\text { NSDP per capita } \\
\text { 2003-04 } \\
\text { (INR, 1993-94 } \\
\text { prices) }\end{array}$ & $\begin{array}{c}\text { Literacy 2001 } \\
\text { (percent) }\end{array}$ & $\begin{array}{c}\text { Rural } \\
\text { Poverty } \\
\mathbf{1 9 9 9 - 2 0 0 0} \\
\text { (percent) }\end{array}$ \\
\hline \hline & & & & & & \\
Gujarat & Rural & Urban & & & & \\
Karnataka & 31.7 & 18.9 & 196.03 & 16,780 & 69.97 & 13.17 \\
Maharashtra & 54.9 & 18.0 & 191.79 & 13,141 & 67.04 & 17.38 \\
Tamil Nadu & 34.8 & 41.1 & 307.72 & 16,479 & 77.27 & 23.72 \\
INDIA & 740.7 & 27.5 & 130.06 & 12,976 & 73.47 & 20.55 \\
\hline
\end{tabular}

Sources: Population, literacy, area - Census of India, 2001; Rural poverty, NSDP - Reserve Bank of India, 2006.

*All-India figure is for Net National Product.

Notes: INR = Indian Rupee, NSDP = Net State Domestic Product

\footnotetext{
${ }^{7}$ While we have a rank ordering of services by revenue contribution for each kiosk, we do not have the exact revenue breakdown by service.
} 
A key issue here is pricing, and, while we do not have complete price data, fieldwork by the second author indicates that the list prices (which also serve as maximum prices) are typically set according to a schedule created by n-Logue, with "price points" chosen to be affordable and socially acceptable. Thus, many basic services are priced in the range INR 5-20. Internet use pricing is based on time spent online. The most expensive service is the provision of horoscopes, which are detailed documents used for match-making. These are priced at about INR 150, most of which goes to a specialized and centralized provider of horoscopes, and not to the kiosk operators.

\section{Table 2: Kiosk Services}

\begin{tabular}{lcl}
\multicolumn{1}{c}{ Service Category } & Frequency* & \multicolumn{1}{c}{ Category Definition } \\
\hline \hline Education & 137 & Online learning \\
Games & 124 & Online or offline computer games \\
Browsing & 62 & $\begin{array}{l}\text { Internet browsing, online match-making, } \\
\text { horoscopes, etc. }\end{array}$ \\
DTP & 51 & DTP access \\
Communications & 32 & Email, videophone, chat \\
Offline Services & 22 & Photoshop, printing, word processing, etc. \\
Results & 9 & Standardized test and academic results \\
Other & 7 & All other \\
\hline
\end{tabular}

* Frequency refers to number of times that a service in this category was listed as the service generating the most revenue in a given month. DTP = Desktop publishing

\section{Determinants of Success}

Since, in most cases, the marginal cost of providing these services is very low relative to the fixed costs of kiosk set-up and operation, the level of revenue is the crucial determining factor in the economic success of a kiosk, and the overall economic sustainability of the model. While there is little flexibility in pricing, the kiosk operator has control over which services to provide and emphasize, how to market them, and the general level of customer service he or she provides. We cannot observe operator effort, 
but can measure operator and kiosk characteristics that may affect both effort and ability. We can also observe various village characteristics which may effect demand. Our goal then is to measure how characteristics of operator, village, and kiosk affect the success of the kiosk.

Table 3: Kiosk and Operator Variables

\begin{tabular}{ll}
\multicolumn{1}{c}{$\begin{array}{c}\text { Operator } \\
\text { Characteristics }\end{array}$} & \multicolumn{1}{c}{ Village/kiosk Characteristics } \\
\hline \hline Age & Province \\
Gender & State \\
Education & Population of village \\
Caste & Distance from district HQ \\
Household size & Distance from big city/metro \\
Own building - Y/N & Monthly facility rent \\
& Services on offer \\
& Kiosk location w/in village \\
& Size of initial loan \\
& Kiosk Investment (self) \\
\hline
\end{tabular}

\section{Salient Features of the Dataset}

The dataset shows various similarities and differences across operators, village, and kiosks, as summarized below.

Operators - As a rule the operators of the kiosks tend to be in their late twenties and early thirties, though the age range extends from 20-45yrs (see Table 4). There are more males than females by a ratio of slightly greater than 2:1 and the males tend to be more educated (see below for more discussion of this point). Only $23 \%$ of the sample owns the building in which they operate, a trait that we find correlates with total revenues but which is not significant when other factors are controlled for. The caste composition of the operators is quite heterogeneous, and many of the original caste designations are 
locally specific. Hence we have aggregated this variable into two salient categories: 1) the backward and scheduled castes (BC/SC) ${ }^{8}$ and 2) other castes.

\section{Table 4: Operator Characteristics Summary Statistics}

\begin{tabular}{l|cccc} 
Characteristics & $\begin{array}{c}\text { Mean or } \\
\text { frequency* }\end{array}$ & Std. dev. & Min. & Max. \\
\hline \hline Age & 29.5 & 5.5 & 20 & 46 \\
Gender (male) & $0.70^{*}$ &.- & 0 & 1 \\
Education: & & & 0 & 1 \\
$\quad$ Some High School & $0.07^{*}$ & - & 0 & 1 \\
High School Graduate & $0.39^{*}$ & - & 0 & 1 \\
College/Technical Degr. & $0.54^{*}$ & - & & 1 \\
Caste: & & & 0 & 1 \\
BC/SC & $0.27^{*}$ & - & 0 & 12 \\
Other & $0.73^{*}$ & - & 2 & 1 \\
Household size & 4.6 & - & 0 & \\
Own building - Y/N & $0.23^{*}$ & - & & \\
\hline
\end{tabular}

\section{Gender/education relationship}

One aspect of the operator data is that there are no men in the least educated subgroup. The sample is $70 \%$ male and $30 \%$ female. We have created three educational categories based on the various responses we found for kiosk operator education level that correspond to some high school, high school graduate, and post secondary degree (the surveys did not show reports of some college so we assume anyone with only some college will be categorized as a high school graduate). Of the women, approximately one quarter are in the some high school category though there are no men in this category (see Table 5). This may represent some feature of the selection process, or it may simply reflect differences in the educational achievement rates for men and women. In India, rural male and female literacy rates were $71.2 \%$ and $46.6 \%$ respectively, for the country as a whole in 2001 . This disparity was greater for adults, at $54.9 \%$ for males and $24.9 \%$

\footnotetext{
${ }^{8}$ Both these terms are specific legal and administrative terms used by the Indian government. Scheduled castes are essentially former "untouchables", and backward castes are other disadvantaged castes with low social status, though not traditionally untouchable.
} 
for females. ${ }^{9}$ Given the disparity in the larger population, the fact that no men with only some high school were observed in the sample may be a purely random outcome.

Villages and Kiosks - Most of the villages are small in absolute size (mean population is just over 5,000), and they are relatively distant from large cities. ${ }^{10}$ Though the average distance of $69 \mathrm{~km}$ to the nearest city may seem like a quick drive, most of the villagers would not have access to a car and would have to rely on slow or infrequent buses and other modes of transport. The kiosks are somewhat closer to district headquarter towns (28.1 $\mathrm{km}$ on average), which simply reflects the administrative geography of India. ${ }^{11}$

\section{Table 5: Gender and Education (percent)}

\begin{tabular}{l|ccrr} 
Gender & $\begin{array}{c}\text { Some } \\
\text { HS }\end{array}$ & $\begin{array}{c}\text { High } \\
\text { School }\end{array}$ & $\begin{array}{c}\text { Post Sec. } \\
\text { Degree }\end{array}$ & Total \\
\hline Male & 0.00 & 25.68 & 44.59 & 70.27 \\
Female & 6.76 & 13.51 & 9.46 & 29.73 \\
Total & 6.76 & 39.19 & 54.05 & 100.00
\end{tabular}

The sample has a large fraction of new kiosks, only a few months old at the start of the observation period. This was due to an effort by n-Logue to sign up new franchisees shortly before the sample period. The nature of the sample may imply that many kiosk owners in this data set are still learning how to operate effectively. This gives an opportunity to examine whether there are learning effects in the data, which would be less likely in a sample of mature kiosks. ${ }^{12}$

\footnotetext{
${ }^{9}$ Literacy statistics are from Planning Commission (2002): while these are reported as being based on the census, the latest census figures for overall literacy (Table 1) show some upward revision for Gujarat, though not the other states. There is also evidence that girls are more likely to drop out of high school than boys, especially in rural India (Planning Commission, 2002, Chapter 4).

${ }^{10}$ Both these characteristics are a deliberate consequence of n-Logue's strategy of targeting truly rural populations, as opposed to those in small towns or on the outskirts of cities.

${ }^{11}$ The district is India's main local administrative unit. The mean area of a district is roughly 5400 square kilometers, which would be a circle with radius about $40 \mathrm{~km}$.

${ }^{12}$ Of course, the relative newness of the whole enterprise implies that "maturity" can have a limited scope, i.e., even long-standing kiosks are just a few years old, and potentially subject to learning effects.
} 


\section{Table 6: Village/Kiosk Variables Summary Statistics}

\begin{tabular}{|c|c|c|c|c|}
\hline Characteristic & $\begin{array}{c}\text { Mean or } \\
\text { frequency* }\end{array}$ & Std dev & Min & Max \\
\hline Population of village & 5318.3 & 6103.8 & 1061 & 35000 \\
\hline $\begin{array}{l}\text { Distance from district HQ } \\
(\mathrm{km})\end{array}$ & 28.1 & 20.5 & 1 & 105 \\
\hline Distance from big & & & & \\
\hline city/metro (km) & 69.3 & 35.4 & 5 & 133 \\
\hline Monthly facility rent & INR 583 & INR 1,383 & INR 0 & INR 12,000 \\
\hline Kiosk age & 6.8 & 5.4 & 1 & 31 \\
\hline Monthly revenue & INR 3,380 & INR 2,853 & INR 100 & INR 23,000 \\
\hline \multicolumn{5}{|l|}{ Kiosk location w/in village: } \\
\hline Bus stop & $0.24 *$ & n.a. & n.a. & n.a. \\
\hline Main road & $0.28 *$ & n.a. & n.a. & n.a. \\
\hline Gov't bldg/commercial & & & & \\
\hline center & $0.22 *$ & n.a. & n.a. & n.a. \\
\hline Neighborhood & $0.26^{*}$ & n.a. & n.a. & n.a. \\
\hline Size of initial loan & INR 42,222 & INR 20,281 & INR 0 & INR 60,000 \\
\hline Kiosk investment (self) & INR 20,757 & INR 24,470 & INR 0 & INR 100,000 \\
\hline
\end{tabular}

Note: At first month of observation, INR/ $\$=43.8$

A summary of the village and kiosk-related characteristics is presented in Table 6. As noted, the kiosks are relatively young, being less than seven months old on average. The average revenue may appear to be quite small, at only INR 3,380. This works out to less than US \$3 per day. Since amortized costs of infrastructure and operating costs are in the range INR 1,000-2,000 per month, the net earnings of kiosk operators are in the region of US \$1 per day, which is the well-known basic international poverty line. However, to the extent that kiosks provide employment to otherwise unemployed, educated rural residents, these earnings may be acceptable, aside from the human capital acquisition that is facilitated thereby. From an economy-wide perspective, those services that are new (and not replacements for costlier methods of delivery) represent a potentially significant addition to economic development. ${ }^{13}$ The average total investment for the sample, at INR 63,000, is representative of the total costs of kiosk equipment for a

\footnotetext{
${ }^{13}$ Building on the analysis of Romer (1994), Singh (2004) shows that ICTs, by reducing transaction costs, may enable the production and exchange of new goods and services, thereby raising long run productivity and development.
} 
variety of such examples, though it does not include the cost of the back-end communication infrastructure. ${ }^{14}$ Finally, in the context of revenues, the high figure reported in Table 6 represents a single extreme outlier - we found that our regression results were highly sensitive to including this kiosk, and our main analysis excludes this observation.

\section{Empirical Strategy}

Most of the variables in our analysis do not vary over time, having been determined either prior to selection as a kiosk operator (e.g. age , gender, caste, etc.) or having been fixed during the kiosk set-up process (e.g. monthly rent). We do have time series observations of the main outcome variable, kiosk monthly revenues, as well as a limited number of other variables at monthly frequency, namely data on how many services were requested by customers and which ones generated the most revenue. Since we do not have good instruments to extract the exogenous variation in the number of services chosen, we do not focus on it in our analysis. ${ }^{15}$ This leaves us with essentially no time variation on the right hand side (RHS). Nevertheless, because we have time-series observations of the LHS variable, which reflect new shock realizations and new choices of effort each period, we are able to treat the dataset as a panel for some specifications.

With these thoughts in mind, we have conducted a few of the standard tests to get a better sense of the stochastic structure of our data and to decide which specific techniques are called for. In summary, we find that there is strong evidence of an individual effects component in the error terms (F-test, not reported). A Breusch-Pagan LM test rejects the null of zero variation in the group effects. Both these results indicate the need to use unobserved effects models rather than simple pooled OLS. We find no

\footnotetext{
${ }^{14}$ The cost of towers and central equipment is either subsidized or recovered through monthly fees for access charged to kiosk operators. Dossani et al (2005) document kiosk equipment and infrastructure costs, and make a case for public subsidies for access. Jhunjhunwala (2000) argues that high interconnection charges and other entry fees unnecessarily raise the cost of network access well beyond basic hardware costs.

${ }^{15}$ Since the pattern of services demanded and the effect on revenue of the types of services offered is still of interest, we did explore some instrumental variable regressions including the number of services - these results are reported on briefly in the paper.
} 
clear evidence either way of autocorrelations in the error structure based on the test from Baltagi and Wu (1999). ${ }^{16}$ The adjusted LM test statistic from Baltagi and Li (1995) only rejects the null of no serial auto correlation at $10 \%$ but not 5\%. A similar test from Baltagi and $\mathrm{Li}$ (1991) of the joint hypothesis of no random effects or serial autocorrelation rejects the null (of neither) at 1\%. We find that the Hausman test does not reject the null that the random effects model parameters are unbiased, indicating the random effects regression is valid, at least on this basis. This test has limited applicability in our data, however, as the only parameters tested for bias are those on variables which do not time-vary (namely, the number of revenue generating services). A likelihood ratio test indicates that the panel displays heteroskedasticity in the error structure so we use robust errors when possible.

There are no econometric techniques that we know of which were developed specifically for a data set that has no time variation on the RHS but which exploit efficiently the variation of the LHS variable. Our approach then has been to check for robustness by running a series of regressions using various techniques. We have chosen the between-effects estimator ${ }^{17}$ as our primary estimation technique. In addition to the practical consideration of wanting to incorporate both time varying and non-time-varying variables, between effects is also theoretically desirable when conducting out of sample predictions (Green 2003). The coefficients estimated by between effects can be used to formulate a prediction of the revenues that would be generated by a new kiosk with certain fixed characteristics. In contrast, estimates using fixed effects net out the individual effect and the impact of time invariant variables, making such a prediction impossible since the fixed effect for an out of sample kiosk is unknown. We would like our results to be relevant to policy discussions which inherently involve out of sample predictions to different locations and situations than the exact ones represented in our sample. We have chosen between-effects for this additional reason.

\footnotetext{
${ }^{16}$ The LBI test statistic of Baltagi and Wu (1999) is 1.81 when including the variables from our standard specification. This is below the critical value of 2 but as the test statistic is highly sensitive to the normality assumption, many authors require a value less than 1.5 to indicate a conclusive result.

${ }^{17}$ The between effects estimator (BEE) regresses group means of the LHS on group means of the RHS variables exploiting only cross sectional variation but using all observations.
} 
We have supplemented the use of the between effects estimator with the random effects estimator, a pooled OLS regression, and the estimator proposed in Baltagi and Wu (1999) which assumes an AR(1) structure in the error terms. Lastly, we have attempted to see what effect varying the number of services has on the total revenue generated by the kiosk. In measuring this effect, there is the obvious problem of endogeneity between the total number of revenue generating services (which are a product of customer need and the efforts of the entrepreneur to promote different services) and the amount of revenue. We attempt to address this by instrumenting the number of services in a two stage procedure but were faced with limited choices of instruments. The instruments we used were a set of dummies for the category of service which was reported as having generated the most revenue in a given period. A Sargan-Hansen test of the over identifying assumptions associated with the instruments cannot reject the null that they are valid instruments; however the instruments we use display very little time variation and are therefore relatively unsuitable.

\section{Results}

In our primary regression specification we use both the owner/operator and the village/kiosk characteristics, putting total revenues on the LHS. As discussed in section 3 we have chosen the between effects estimator as our primary estimation technique for a variety of reasons and supplemented this technique with other techniques for robustness. Our primary regression results are presented in Table 7, with the main estimating equation being the first column of Table 7a labeled "Between Effects - Baseline". As noted earlier in this section, we omitted a single outlier in these specifications. ${ }^{18}$ Looking at the baseline specification, we see that the age variable as well as the dummy for backwards and scheduled castes and the dummies for being located on the main road or

\footnotetext{
${ }^{18}$ The full sample results are reported in the third regression in Table $7 \mathrm{~b}$, and are quite different in their implications. On the other hand, omitting further outliers, as in the third regression in Table 7a, or just estimating the specification for Tamil Nadu (the second regression in Table 7a) makes little difference to the results, in terms of signs and significance of coefficients.
} 
commercial center are all significant at 5\% level. ${ }^{19}$ Household size and the state dummy for Karnataka State are also significant at $10 \%$ level. This pattern plays out fairly consistently across the other specifications and is discussed below.

We also run a more parsimonious regression with fewer kiosk characteristics and dummies for education and schooling collapsed into binary indicators. This specification did not find any significant deviations from the above results indicating that multicollinearity is not likely a problem. Similarly, we employ the technique from Baltagi and Wu (1999) which accounts for autocorrelation in the residuals and the results are largely the same. Finally, we split the sample as a robustness check and conduct some regressions using instrumental variables to sort out the relationship between the number of services reported as having generated revenue and the total revenues. The results of these regressions are discussed below. ${ }^{20}$

Location - Kiosks which are near to a main road of their village or a commercial building are significantly more profitable than those in other locations within the village (divided into main road, residential, commercial/government building, and bus stop). Despite the age-old maxim that the three most important determinants of success in retail are location, location, location, we still find this result surprising. The villages where these kiosks operate are relatively small and the advent of an Internet kiosk should be relatively well known whether it appears in a visible central location, or not.

In many villages, neighborhoods segregate by caste. This can cause certain parts of town to be undesirable destinations for some village residents from other areas. A main road or commercial center location would likely be a caste-neutral spot that would encourage the greatest number of customers to visit the kiosk without fear of being seen on the "wrong side of town." In the paired down specification ("fewer regressors" in

\footnotetext{
${ }^{19}$ To get a higher resolution view of the social/cultural effects driving the significance of caste and age we tried interacting the variables age, caste, education, and gender with each other in various specifications but found no statistically significant interaction terms.

${ }^{20}$ All our regressions are linear in the variables. Log-log and semi-log regressions preserved the signs, but statistical significance was lost because the degree of variation in the data was reduced by the log transformation.
} 
table 7a) we find that a combined dummy coding for non-residential location is highly significant.

Another possible explanation may be that some remote villages are not located along a "main road" and do not have a large commercial center at all and that this choice may not have been available to those kiosk owners. Thus the measured effect of "main road" may proxy for a more developed village that is along a main road rather than the effect of relative location within the village. ${ }^{21}$

A final factor that may play a minor role in this result is that many of the kiosks were founded a short time before the beginning of the sample period. The increased local visibility by being in a commercial center may have driven initial revenues especially to individuals from surrounding areas who enter the village infrequently.

Social Status - It seems that social status as measured by greater age and caste plays a significant role in determining the revenues generated by each kiosk. While we cannot be sure of the channel through which this effect operates some obvious candidates come to mind. Individuals with higher social standing may have larger and more affluent social networks through which to advertise their services to the village and surrounding areas. They may be more effective in convincing a skeptical population of the value of these services. They may also possess greater human capital, making them more effective business operators in other ways. ${ }^{22}$ Interestingly, the caste variable was least significant and of smallest magnitude in Tamil Nadu, which underwent an early social revolution involving the rise of scheduled and backward castes in a "self-respect movement."23

\footnotetext{
${ }^{21}$ The level of development can obviously affect the demand for IT-enabled services. For example, in remote villages with poor transportation facilities, a higher percentage of the farming activity may be dedicated to subsistence farming rather than commercial farming that would be complementary with Internet services for conducting price discovery, orders of farming inputs, and financial transactions.

${ }^{22}$ We also examined the possibility that caste could be proxying for an unobserved characteristic of the district within which the kiosk was located, by replacing state-level dummies with district dummies.

However, none of the district dummies was significant in the estimated regressions.

${ }^{23}$ See, for example, Béteille (1965) for an early discussion of the sociological impacts of this movement on rural Tamil Nadu.
} 
Tamil Nadu is also more densely populated, and relatively urbanized, factors which may contribute to greater contemporary social fluidity.

Household size - Household size is significant at $10 \%$ in the main specification and in a number of the alternate regressions. This most likely indicates that household members are being conscripted to work at the family business, allowing longer hours and service of more customers. It could also represent larger a social network through which to advertise services, though we believe that the former effect is likely to have greater impact.

\section{Insignificant Factors}

Almost as interesting as the statistically significant factors are those which are not significant. Much attention is paid in development circles to concepts of fairness, income inequality and empowerment of women. We find that while caste is a significant determinant of success, gender and education are not. ${ }^{24}$

Gender - While fully one third of the sample are women, the gender dummy is not even close to significant in any specification. We believe this argues in favor of the notion that entrepreneurial opportunities are not significantly biased against women at the village level. There may still be biases in terms of educational attainment and other factors. However, these biases, if they exist, are not measurably affecting the outcome and are probably corrected during the entrepreneur selection process. It is notable that women are over represented in the least educated subgroup indicating that the franchisee selection process is not holding women to a higher educational standard. ${ }^{25}$

Education - None of the education dummies are significant at $5 \%$ or $10 \%$ in the main specification nor in any of the supplementary regressions except pooled OLS,

\footnotetext{
${ }^{24}$ In addition to the fact that gender and education were not significant, we were also surprised by the fact that ownership of the kiosk was not a significant determinant of success. We investigated this issue further by estimating a probit regression on the determinants of ownership and found that none of the owner or village variables were significant in affecting whether a kiosk location was owned or rented.

${ }^{25}$ While it is possible that women are used as "fronts" for men if the selection process is designed to favor women in some way, there was no indication from the second author's field interviews that this was happening.
} 
which shows an advantage that is greater for high school than for college grads. Statistically, having finished high school and/or some college gives no advantage over having never finished high school at all, where this last category does have more than a minimal level of secondary education. This result is noteworthy given the technical nature of the tasks that operators must perform. The fact that n-Logue screens and trains individuals on the equipment may help correct for lack of education beyond the basic cutoff level.

Given that it is often the economically disadvantaged who achieve lower levels of education, we take these results as a hopeful sign that the sustainable franchise model offers opportunities to groups which have been disadvantaged in the past. This feature is a nice one as it indicates benefits of the model that extend beyond the direct economic impact of the services which it delivers.

Population - None of the specifications reported indicate that the size of the village has any bearing on the amount of revenues generated by the kiosk. We find this result both surprising and very robust (in unreported regressions, all variables which significantly correlate with population were dropped sequentially and the coefficient was still not significant, indicating multicollinearity with other village characteristics is not confounding the results).

The result is surprising, because one would expect the size of the economic catchment would be a measure of market size and a significant determinant of the level of revenues. We surmise that the size of the village is not at all a measure of the relevant economic catchment, and that either the kiosks are catering to markets larger than the village due to customers' willingness to travel, or markets which are smaller than most of the villages in the sample. Based on field observations, we believe the former explanation is more likely.

Revenue Services - We attempted to instrument the number of services reported as having generated revenue using dummies for which category of service was reported as being the top revenue generator. In Table $7 \mathrm{~b}$, the estimated parameter on instrumented number of revenue services is not significant. This most likely reflects the weakness of 
the instruments and we do not take it as a conclusive finding. While the instruments pass a likelihood ratio test for over-identifying restrictions, they do not vary much over time within kiosk (most kiosks report the same top service across the six months; a few show the top service changing over time). In the raw data, these two variables (total revenue and number of revenue generating services) are very highly correlated. We cannot differentiate between the conclusion that choosing the number of revenue services to offer causally influences the amount of revenues generated and the alternative that the number of revenue generating services is determined by demand and therefore only correlated with revenue. Without better instruments, we find it difficult to determine causality with respect to the choice of services offered in the kiosks. 
Internet Kiosks in Rural India: What Influences Success?

\section{Table 7a: Regression Results}

\begin{tabular}{|c|c|c|c|c|c|c|c|c|}
\hline $\begin{array}{l}\text { Total Revenues } \\
\text { (LHS) }\end{array}$ & $\begin{array}{c}\text { Between } \\
\text { Effects^ } \\
\text { Baseline }\end{array}$ & $\mathbf{t}$ & $\begin{array}{c}\text { Between } \\
\text { Effects } \wedge \wedge \text { - } \\
\text { Parsimonious } \\
\text { Specification }\end{array}$ & $\mathbf{t}$ & $\begin{array}{c}\text { Random } \\
\text { Effects^ } \\
\text { Baseline }\end{array}$ & $\mathbf{z}$ & $\begin{array}{c}\text { Between } \\
\text { Effects } \wedge_{-} \\
\text {Tamil Nadu } \\
\text { Only }\end{array}$ & $\mathbf{t}$ \\
\hline $\begin{array}{l}\text { Total Services } \\
\text { Population } \\
\text { Pop*Town } \\
\text { Age } \\
\text { Female (d) } \\
\text { HH Size } \\
\text { Kiosk Owner (d) }\end{array}$ & $\begin{array}{r}-0.013 \\
0.012 \\
\mathbf{7 8 . 9 3 7} \\
178.299 \\
\mathbf{2 0 9 . 3 7 9} \\
819.352\end{array}$ & $\begin{array}{r}-(0.38) \\
(0.34) \\
\underline{(2.20)} \\
(0.39) \\
(1.77) \\
(1.52)\end{array}$ & $\begin{array}{r}-0.030 \\
0.029 \\
\mathbf{9 8 . 4 9 1} \\
313.052 \\
\mathbf{1 9 8 . 3 8 8} \\
\mathbf{8 2 0 . 8 3 3}\end{array}$ & $\begin{array}{r}-(0.99) \\
(0.95) \\
(3.02) \\
(0.75) \\
(\mathbf{1 . 8 0 )} \\
(\mathbf{1 . 6 9 )}\end{array}$ & $\begin{array}{r}-0.012 \\
0.011 \\
\mathbf{7 6 . 0 4 4} \\
170.089 \\
\mathbf{2 1 5 . 0 6 0} \\
856.520\end{array}$ & $\begin{array}{r}-(0.49) \\
(0.44) \\
(\mathbf{1 . 8 7 )} \\
(0.35) \\
\underline{(\mathbf{( 2 . 1 4 )}} \\
(1.36)\end{array}$ & $\begin{array}{r}-0.057 \\
0.057 \\
\mathbf{1 2 1 . 7 1 7} \\
466.833 \\
186.779 \\
-125.977\end{array}$ & $\begin{array}{r}-(1.24) \\
(1.23) \\
(2.84) \\
(0.76) \\
(1.32) \\
-(0.12)\end{array}$ \\
\hline $\begin{array}{l}\text { Education Dummies: } \\
\text { Some HS (d) } \\
\text { HS (d) } \\
\text { Some College (d) } \\
\text {---Educated(d) } \wedge \wedge \wedge\end{array}$ & $\begin{array}{c}\text { (omitted d } \\
1132.877 \\
660.954\end{array}$ & $\begin{array}{l}\text { my) } \\
(1.27) \\
(0.72)\end{array}$ & $\begin{array}{l}\text { (omitted du } \\
1026.706\end{array}$ & $(1.40)$ & $\begin{array}{r}\text { (omitted d } \\
1081.869 \\
610.580\end{array}$ & $\begin{array}{l}\text { Imy) } \\
(1.25) \\
(0.87)\end{array}$ & $\begin{array}{r}\text { (omitted du } \\
822.862 \\
763.051\end{array}$ & $\begin{array}{l}\text { ny) } \\
(0.83) \\
(0.73)\end{array}$ \\
\hline $\begin{array}{l}\text { Low Caste (d) } \\
\text { Self Invest } \\
\text { Loan Size } \\
\text { Monthly Rent } \\
\text { Kiosk Age }\end{array}$ & $\begin{array}{r}\mathbf{- 1 1 6 0 . 0 2 3} \\
-0.004 \\
-0.011 \\
0.215 \\
-33.169\end{array}$ & $\begin{array}{r}\frac{-(2.03)}{-(0.28)} \\
-(0.88) \\
(1.19) \\
-(0.83)\end{array}$ & $\underline{-940.519}$ & $\underline{-(2.40)}$ & $\begin{array}{r}\mathbf{- 1 1 5 6 . 6 1 8} \\
-0.004 \\
-0.013 \\
0.219 \\
-46.733\end{array}$ & $\begin{array}{r}\frac{-(2.73)}{-(0.17)} \\
-(0.75) \\
(1.05) \\
-(1.41)\end{array}$ & $\begin{array}{r}-860.356 \\
0.001 \\
-0.017 \\
-0.428 \\
0.307\end{array}$ & $\begin{array}{r}-(1.03) \\
(0.04) \\
-(1.02) \\
-(0.35) \\
(0.01)\end{array}$ \\
\hline $\begin{array}{l}\text { Location Dummies: } \\
\text { Comm Bldg (d) } \\
\text { Bus Stop (d) } \\
\text { Main Road (d) } \\
\text { Residential (d) } \\
\text {---Non-residential } \\
\text { (d) } \wedge \wedge \wedge\end{array}$ & $\begin{array}{r}\mathbf{1 0 6 6 . 3 0 7} \\
534.597 \\
\mathbf{1 6 0 5 . 5 0 0} \\
\text { (omitted d }\end{array}$ & $\begin{array}{l}\mathbf{( 1 . 7 5 )} \\
(0.94) \\
(2.73) \\
\text { my) }\end{array}$ & $\begin{array}{l}\text { (omitted du } \\
\mathbf{1 0 4 8 . 2 4 2}\end{array}$ & $\begin{array}{l}\text { ny) } \\
\text { (2.59) }\end{array}$ & $\begin{array}{r}\mathbf{1 0 8 0 . 8 8 8} \\
546.533 \\
\mathbf{1 6 4 1 . 3 6 5} \\
\text { (omitted d }\end{array}$ & $\begin{array}{l}\mathbf{( 1 . 9 5 )} \\
(1.11) \\
\mathbf{( 2 . 0 1 )} \\
\text { Imy) }\end{array}$ & $\begin{array}{r}1251.414 \\
1501.159 \\
2143.774 \\
\text { (omitted du }\end{array}$ & $\begin{array}{l}(1.77) \\
(1.96) \\
(2.84) \\
y)\end{array}$ \\
\hline $\begin{array}{l}\text { Distance HQ } \\
\text { Distance City } \\
\text { Karnataka (d) } \\
\text { Gujarat (d) } \\
\text { Maharashtra (d) } \\
\text { _cons }\end{array}$ & $\begin{array}{r}-5.343 \\
2.137 \\
\mathbf{- 1 6 1 1 . 0 6 6} \\
1531.892 \\
409.218 \\
-671.730\end{array}$ & $\begin{array}{r}-(0.38) \\
(0.22) \\
-(1.73) \\
(1.25) \\
(0.54) \\
-(0.32)\end{array}$ & $\begin{array}{r}\mathbf{- 9 4 3 . 5 7 5} \\
\mathbf{1 7 0 3 . 3 9 0} \\
31.494 \\
-2275.739\end{array}$ & $\begin{array}{r}-(1.99) \\
(\mathbf{2 . 0 4 )} \\
(0.05) \\
-(1.51)\end{array}$ & $\begin{array}{r}-5.025 \\
1.493 \\
-1586.722 \\
1514.316 \\
375.241 \\
-355.380\end{array}$ & $\begin{array}{r}-(0.33) \\
(0.15) \\
-(1.24) \\
(1.16) \\
(0.61) \\
-(0.17)\end{array}$ & $\begin{array}{r}1.747 \\
10.851\end{array}$ & $\begin{array}{l}(0.10) \\
(0.79)\end{array}$ \\
\hline $\begin{array}{c}\wedge(\mathrm{i}=73, \mathrm{t}=\mathbf{6}) \\
\wedge \wedge(\mathrm{i}=\mathbf{4 7 , t}=\mathbf{6})\end{array}$ & $\begin{array}{c}\mathrm{N}=438 \\
(73 \text { grps) } \\
\text { Pseudo - } \mathbf{R}^{2} \\
\quad=.26\end{array}$ & & $\begin{array}{c}\mathrm{N}=438 \\
(73 \text { grps }) \\
\text { Pseudo }-\mathbf{R}^{2} \\
\quad=.23\end{array}$ & & $\begin{array}{c}\mathrm{N}=438 \\
\text { Pseudo - } \mathrm{R}^{2} \\
\quad=.26\end{array}$ & & $\begin{array}{c}\mathrm{N}=282 \\
\begin{array}{l}\text { Pseudo - } \mathbf{R}^{2} \\
\quad=.23\end{array}\end{array}$ & \\
\hline
\end{tabular}

Notes: $(d)=$ dummy variable, Bold underline are significant at $5 \%$, Bold are significant at $10 \%$

$\wedge \wedge \wedge$ Educated is HS graduate and above. Non-residential is a dummy for all three of commercial building, or bus stop, or main road. 
Internet Kiosks in Rural India: What Influences Success?

Table 7b: Supplementary Regression Results

\begin{tabular}{|c|c|c|c|c|c|c|c|c|}
\hline $\begin{array}{l}\text { Total Revenues } \\
\text { (LHS) }\end{array}$ & $\begin{array}{c}\text { AR(1) } \\
\text { Errors } \\
\text { (RE)^ - }^{\wedge} \text { Baseline } \\
\end{array}$ & $\mathbf{z}$ & $\begin{array}{c}\text { Between } \\
\text { Effects^^ - } \\
\text { Bootstrapped }\end{array}$ & $\begin{array}{l}\text { boot- } \\
\text { strapped } \\
\quad \text { z }\end{array}$ & $\begin{array}{c}\text { Random } \\
\text { Effects^ }{ }^{\wedge} \text { IV } \\
\text { on services }\end{array}$ & $\mathbf{z}$ & $\begin{array}{l}\text { Pooled OLS } \\
\text { - Baseline }\end{array}$ & $\begin{array}{c}\mathrm{t} \\
\text { (robust) }\end{array}$ \\
\hline $\begin{array}{l}\text { Total Services } \\
\text { Population } \\
\text { Pop*Town } \\
\text { Age } \\
\text { Female (d) } \\
\text { HH Size } \\
\text { Kiosk Owner (d) }\end{array}$ & $\begin{array}{r}-0.013 \\
0.011 \\
\mathbf{7 7 . 7 3 2} \\
151.425 \\
\underline{\mathbf{2 0 7 . 3 9 1}} \\
\mathbf{8 2 4 . 6 7 5}\end{array}$ & $\begin{array}{r}-(0.43) \\
(0.39) \\
\underline{(2.60)} \\
(0.39) \\
\underline{(2.09)} \\
\mathbf{( 1 . 8 2 )}\end{array}$ & $\begin{array}{r}-0.013 \\
0.012 \\
\mathbf{7 8 . 9 3 7} \\
178.299 \\
209.379 \\
819.352\end{array}$ & $\begin{array}{r}-(0.28) \\
(0.26) \\
(1.80) \\
(0.33) \\
(1.63) \\
(1.07)\end{array}$ & $\begin{array}{r}105.529 \\
-0.015 \\
0.014 \\
\mathbf{7 8 . 0 7 1} \\
92.139 \\
181.968 \\
705.933\end{array}$ & $\begin{array}{r}(0.60) \\
-(0.46) \\
(0.42) \\
(2.30) \\
(0.20) \\
(1.46) \\
(1.24)\end{array}$ & $\begin{array}{r}-0.013 \\
0.011 \\
\underline{\mathbf{7 8 . 0 0 3}} \\
175.650 \\
\underline{\mathbf{2 1 1 . 2 1 2}} \\
\underline{\mathbf{8 3 1 . 3 4 8}} \\
\end{array}$ & $\begin{array}{r}-(0.88) \\
(0.79) \\
\underline{(3.81)} \\
(0.70) \\
\underline{\mathbf{( 3 . 8 8 )}} \\
\underline{\mathbf{( 2 . 6 1 )}} \\
\end{array}$ \\
\hline $\begin{array}{l}\text { Education Dummies: } \\
\text { Some HS (d) } \\
\text { HS (d) } \\
\text { Some College (d) } \\
\text {---Educated(d) }\end{array}$ & $\begin{array}{c}\text { (omitted de } \\
1130.229 \\
657.474\end{array}$ & $\begin{array}{l}\text { Imy) } \\
(1.51) \\
(0.85)\end{array}$ & $\begin{array}{c}\text { (omitted du } \\
1132.877 \\
660.954\end{array}$ & $\begin{array}{l}\text { nmy) } \\
(1.35) \\
(0.79)\end{array}$ & $\begin{array}{r}\text { (omitted du } \\
1036.396 \\
570.033\end{array}$ & $\begin{array}{l}\text { y) } \\
(1.22) \\
(0.65)\end{array}$ & $\begin{array}{r}\text { (omitted } d \\
\underline{\mathbf{1 1 1 6 . 4 1 5}} \\
\mathbf{6 4 4 . 6 9 6}\end{array}$ & $\begin{array}{l}\text { mmy) } \\
\qquad \frac{(2.56)}{(1.74)}\end{array}$ \\
\hline $\begin{array}{l}\text { Low Caste (d) } \\
\text { Self Invest } \\
\text { Loan Size } \\
\text { Monthly Rent } \\
\text { Kiosk Age }\end{array}$ & $\begin{array}{r}\mathbf{- 1 1 8 6 . 4 6 0} \\
-0.004 \\
-0.011 \\
0.211 \\
-33.270\end{array}$ & $\begin{array}{r}\frac{-(2.46)}{-(0.33)} \\
-(1.01) \\
(1.39) \\
-(1.19)\end{array}$ & $\begin{array}{r}-\mathbf{- 1 1 6 0 . 0 2 3} \\
-0.004 \\
-0.011 \\
0.215 \\
-33.169\end{array}$ & $\begin{array}{r}\frac{-(2.07)}{-(0.21)} \\
-(0.70) \\
(0.31) \\
-(0.74)\end{array}$ & $\begin{array}{r}\mathbf{- 1 1 4 1 . 4 4 4} \\
0.000 \\
-0.011 \\
0.201 \\
-33.889\end{array}$ & $\begin{array}{r}-(2.09) \\
-(0.02) \\
-(0.89) \\
(1.16) \\
-(0.97)\end{array}$ & $\begin{array}{r}\mathbf{- 1 1 5 8 . 9 2 4} \\
-0.004 \\
-0.012 \\
\mathbf{0 . 2 1 6} \\
-\mathbf{3 7 . 5 4 7}\end{array}$ & $\begin{array}{r}\frac{-(4.93)}{-(0.35)} \\
-(1.37) \\
\frac{(2.17)}{-(1.75)}\end{array}$ \\
\hline $\begin{array}{l}\text { Location Dummies: } \\
\text { Comm Bldg (d) } \\
\text { Bus Stop (d) } \\
\text { Main Road (d) } \\
\text { Residential (d) } \\
\text {----Non-residential } \\
\text { (d) }\end{array}$ & $\begin{array}{r}\frac{\mathbf{1 0 5 2 . 4 2 4}}{552.775} \\
\mathbf{1 6 0 1 . 0 5 2} \\
\text { (omitted du }\end{array}$ & $\begin{array}{r}\frac{(2.05)}{(1.16)} \\
\underline{(3.25)} \\
\text { my) }\end{array}$ & $\begin{array}{r}1066.307 \\
534.597 \\
\mathbf{1 6 0 5 . 5 0 0} \\
\text { (omitted du }\end{array}$ & $\begin{array}{r}(1.34) \\
(0.63) \\
(2.05) \\
\text { nmy) }\end{array}$ & $\begin{array}{r}\mathbf{1 0 2 8 . 1 9 5} \\
537.864 \\
\mathbf{1 5 5 6 . 0 1 9} \\
\text { (omitted du }\end{array}$ & $\begin{array}{l}(1.75) \\
(0.99) \\
(2.71) \\
\underline{y})\end{array}$ & $\begin{array}{r}\frac{1071.013}{538.450} \\
\underline{1617.075} \\
\text { (omitted d }\end{array}$ & $\begin{array}{r}\frac{(3.56)}{(1.75)} \\
\underline{(3.79)} \\
m y)\end{array}$ \\
\hline $\begin{array}{l}\text { Distance HQ } \\
\text { Distance City } \\
\text { Karnataka (d) } \\
\text { Gujrat (d) } \\
\text { Maharashtra (d) } \\
\text { _cons }\end{array}$ & $\begin{array}{r}-5.332 \\
2.197 \\
\mathbf{- 1 6 4 7 . 6 0 3} \\
1436.112 \\
432.760 \\
-639.606 \\
\end{array}$ & $\begin{array}{r}-(0.45) \\
(0.27) \\
-(2.10) \\
(1.39) \\
(0.68) \\
-(0.37) \\
\end{array}$ & $\begin{array}{r}-5.343 \\
2.137 \\
-1611.066 \\
1531.892 \\
409.218 \\
-671.730 \\
\end{array}$ & $\begin{array}{r}-(0.28) \\
(0.19) \\
-(1.37) \\
(0.89) \\
(0.38) \\
-(0.30) \\
\end{array}$ & $\begin{array}{r}-7.062 \\
2.156 \\
\mathbf{- 1 7 3 0 . 7 6 9} \\
1647.656 \\
473.150 \\
-807.166 \\
\end{array}$ & $\begin{array}{r}-(0.51) \\
(0.23) \\
-(1.88) \\
(1.38) \\
(0.64) \\
-(0.39) \\
\end{array}$ & $\begin{array}{r}-5.240 \\
1.929 \\
\mathbf{- 1 6 0 3 . 2 0 9} \\
\mathbf{1 5 2 6 . 2 2 0} \\
398.252 \\
-569.631 \\
\end{array}$ & $\begin{array}{r}-(0.63) \\
(0.35) \\
-(2.54) \\
\frac{(2.10)}{(1.08)} \\
-(0.52)\end{array}$ \\
\hline $\begin{array}{r}\wedge(\mathrm{i}=73, \mathrm{t}=6) \\
\wedge \wedge(\mathrm{i}=\mathbf{4 7}, \mathrm{t}=\mathbf{6})\end{array}$ & $\begin{array}{c}\mathrm{N}=438 \\
\begin{array}{l}\text { Pseudo - } \mathbf{R}^{2} \\
\quad=.26\end{array}\end{array}$ & $\begin{array}{c}\text { rho-AR } \\
=.25 \\
\text { LBI } \\
=1.8\end{array}$ & $\begin{array}{c}\mathrm{N}=282 \\
\begin{array}{l}\text { Pseudo }-\mathbf{R}^{2} \\
\quad=.26\end{array}\end{array}$ & $\begin{array}{l}50 \text { b.s. } \\
\text { iteration }\end{array}$ & $\begin{array}{c}\mathrm{N}=438 \\
\begin{array}{l}\text { Pseudo - } \mathbf{R}^{2} \\
\quad=. \mathbf{3 0}\end{array}\end{array}$ & & $\begin{array}{c}\mathrm{N}=438 \\
\mathbf{R}^{2}=\mathbf{0 . 3 3}\end{array}$ & \\
\hline
\end{tabular}

Notes: $(d)=$ dummy variable, Bold underline are significant at 5\%, Bold are significant at $10 \%$

$\wedge \wedge$ Non-residential is a dummy for all three of commercial building, or bus stop, or main road. Educated is HS graduate and above. 


\section{Pent-up Demand, Learning by Doing, and Seasonality Issues}

The median kiosk age in month one of the survey is only six months and many kiosks are only a month or two old when the survey starts. This allows us to investigate the revenue dynamics in the early stages of the kiosk life. One hypothesis might be that the kiosks should initially see large revenues as they fill pent up demand due to curiosity or one-off tasks which are not soon repeated (emails to overseas relatives, photoshopping of old wedding photos, etc.) but that the demand would shortly drop off to its steady state level. An alternative hypothesis would be that as kiosk owners learn their business and generate awareness in their local market their revenues should build from an initially low level. Fieldwork by one of the authors (Singh, 2004a) suggests that, depending on the situation, both effects operate in practice.

In Figure 2 we have plotted the average revenue and the number of revenue services reported over time in three different groups, the youngest $50 \%$ of kiosks, the oldest 50\%, and the total sample. Clearly, seasonal effects seem to be at play given that the older and younger samples both have similar variation over time. To the extent that trends differ in the young kiosks vs. the old we can learn something about how the new kiosks are transitioning to the steady state. We can see that the newer kiosks have growing revenues over time and growing revenues per service as opposed to the older kiosks which exhibit no trend in either. Though the effects are small relative to the seasonal variation, this is consistent with a description allowing for positive learning effects. If there is learning, however, it is impossible to determine whether it is learning by the operator, the village population, or by n-Logue. 


\section{Figure 2: Revenue and Services Dynamics}
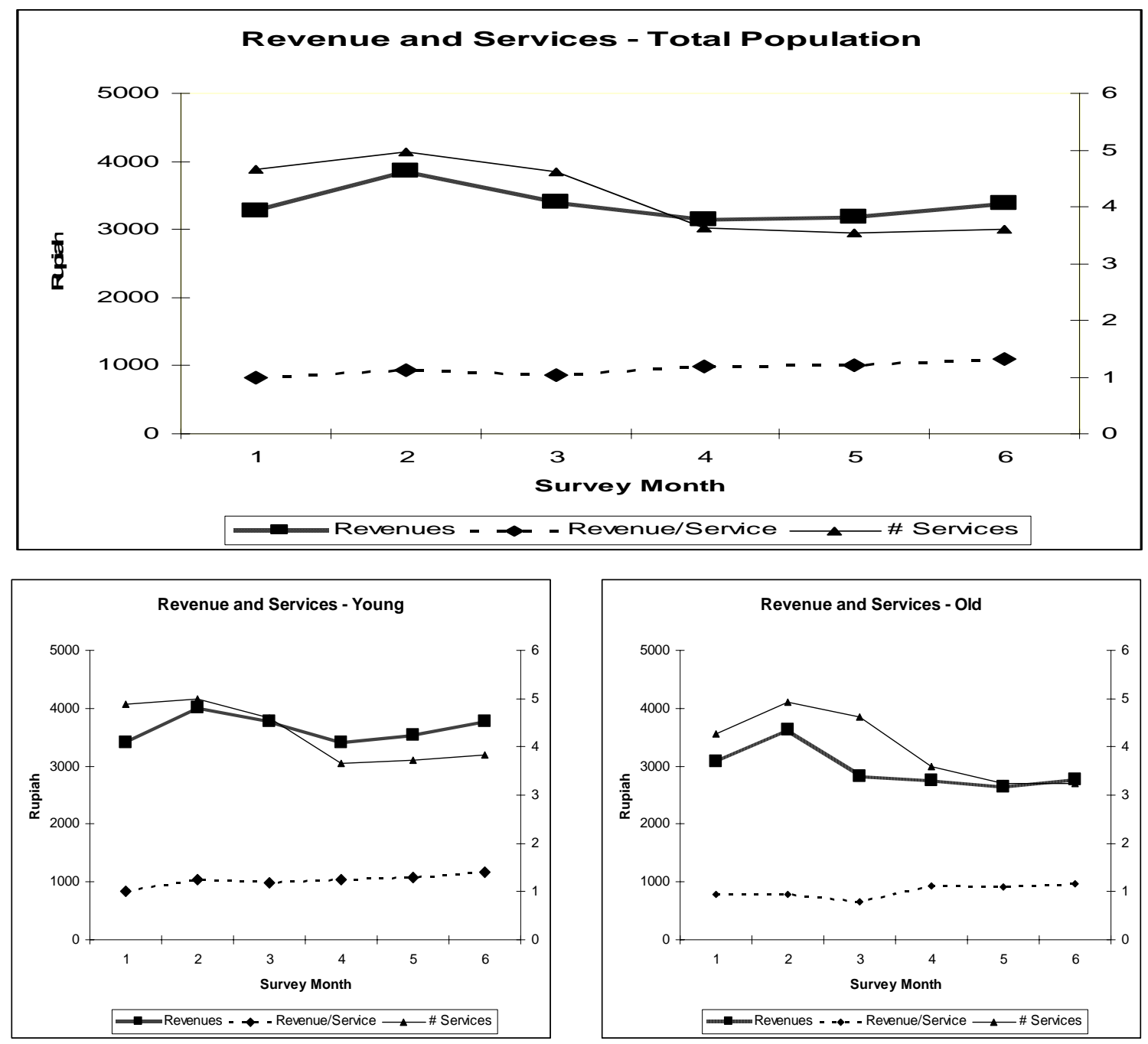

It is interesting to note that the average revenue of the youngest $50 \%$ of kiosks is somewhat higher than in the older sample. As can be seen in Figure 3, the firms fall into two fairly distinct age groups that reflect the initial and recent recruitment campaigns on the part of n-Logue. The higher average revenue of the newer kiosks may reflect a learning curve on the part of n-Logue in their selection process and training regime. ${ }^{26}$

\footnotetext{
${ }^{26}$ We note that average kiosk ages do not differ significantly across the four states, so that geographic variation at that level cannot be the explanation for the observed pattern as discussed here.
} 
Figure 3: Histogram, Kiosk Age at Start of Survey

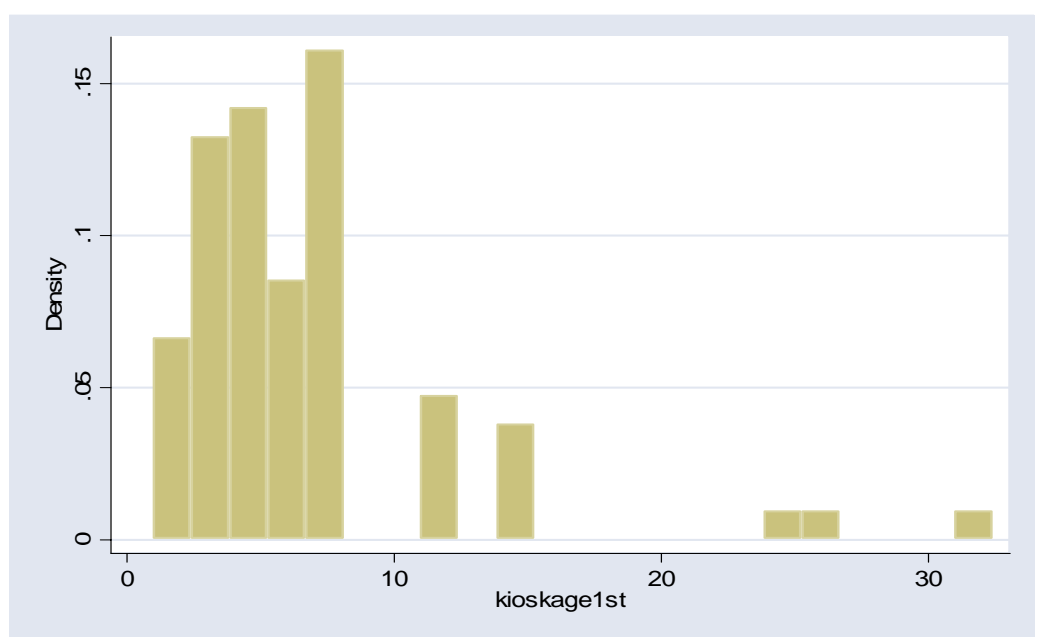

In both the new and old kiosks, there seems to be a seasonal component to revenues, evident as the sinusoidal variation in both samples. The sample period starts just before the monsoon season and carries through until September as the monsoons are just beginning to ebb. During this time, farmers will likely have made a large investment in seed, fertilizer, and other agricultural inputs and will not receive pay-off until late September or early October when much of the harvest is sold. This may account for the initially high revenues which drop off during July, August, and September (a pattern we observe in both the young and old kiosk groups). If a seasonal variation in income affects demand or if a main driver of demand is harvest related tasks such as price discovery, government services, banking, purchases of farming inputs, etc. then for both these reasons we might expect the seasonal component of demand faced by the kiosks to be low and or declining in this period as it is in the data.

\section{Uses for Services}

We have limited data on the services that were requested by the customers of the Internet kiosk. In the development literature, many have speculated as to the beneficial uses that rural village residents would have for telephones and the Internet. Often these speculations have centered on commercial activities and access first world markets and distant services. Being able to sell local products to first world consumers, accessing medical care via videophone, price discovery for agricultural production, are some oft 
cited examples. Our data are not fine grained enough to completely address the usage question directly but we do have a rough indication of what services were being requested. In Table 8, we have listed the top three reported revenue generating services by state. In general, education and DTP (desk top publishing) services are the highest requested service followed closely by games with games seeming to play a slightly more prominent role in the richer state of Maharashtra, but also in somewhat poorer Tamil Nadu. Both states do have high literacy rates, though this may or may not be a determining factor in the demand for online games.

Table 8: Highest Revenue Generating Services by State

\begin{tabular}{lr|lr|lr|lr}
\hline Maharashtra & $\begin{array}{l}\text { Freq. as } \\
\text { highest }\end{array}$ & $\begin{array}{l}\text { Tamil } \\
\text { Nadu }\end{array}$ & $\begin{array}{l}\text { Freq. as } \\
\text { highest }\end{array}$ & Gujarat & $\begin{array}{l}\text { Freq. as } \\
\text { highest }\end{array}$ & Karnataka & $\begin{array}{l}\text { Freq. as } \\
\text { highest }\end{array}$ \\
\hline \hline Education & 0.40 & Games & 0.37 & Education & 0.44 & Education & 0.83 \\
DTP & 0.18 & Browsing & 0.21 & Offline & 0.28 & Games & 0.11 \\
Games & 0.17 & DTP & 0.12 & DTP & 0.11 & DTP & 0.04 \\
Comm. Svcs. & 0.10 & Education & 0.12 & Test Results & 0.11 & Offline & 0.02 \\
\hline
\end{tabular}

Going back to the full list of services in Table 1, we can reiterate the earlier point that the mix of services are not much different that what one might expect from Internet users in a developed country (browsing, chat and VOIP, education, games, on-line match making, horoscopes, etc).

We should add here that fieldwork interviews by one of the authors (Singh) with users, kiosk operators, and n-Logue staff suggested that, through a process of social norms and expectations, kiosk operators provide a certain amount of free services that include remote health diagnosis, agricultural techniques and disease information, and basic education. 


\section{Conclusions}

Our empirical results point to a number of factors that determine the success of a franchise model in the rural context and a number that do not. We find that education and gender do not significantly affect kiosk profits but that the caste designation and age of the kiosk operator does. It seems that while local social norms and practices can have a negative impact on profits (caste discrimination), stringent entrepreneur selection standards and good training can overcome some barriers (such as gender bias). ${ }^{27}$ This leads us to the conclusion that, as program designers choose where to locate their programs, who to recruit, etc., they should carefully take into account the local customs and practices but not be biased by preconceived notions of who will be successful and what modes of operation will work best. Additionally, they may want to look for opportunities to target goals beyond the delivery of IT-services such as developing entrepreneurial and technical skills in the population and empowering women and other minorities.

Seasonality and learning effects seem to be significant factors that may pose special challenges for designers of similar programs in other parts of the world. N-Logue has a phased cost approach where the kiosk operator's franchise fees increase gradually over the course of a year so that the operator has time to learn the business and generate awareness. This approach seems to have worked well in giving operators a necessary grace period.

\footnotetext{
${ }^{27}$ While our analysis did not bear out anecdotal claims that woman entrepreneurs do better than men, the fact that they do no worse in a non-traditional, entrepreneurial occupation is itself a noteworthy finding.
} 


\section{References}

Béteille, André (1965), Caste, Class, and Power: Changing Patterns of Stratification in a Tanjore Village, Berkeley: University of California Press.

Baily, Martin N., 2004, Recent Productivity Growth: The Role of Information Technology and Other Innovations, Federal Reserve Bank of San Francisco Economic Review, April, 35-41.

Black, Sandra and L. Lynch, (2004), "What's Driving the New Economy?: The Benefits of Workplace Innovation”, The Economic Journal, 114 (February), F97-F116.

Bresnahan, Timothy, Erik Brynjolfsson, and Lorin Hitt, (2002), “Information Technology Workplace Organization and the Demand for Skilled Labor: Firm Level Evidence,” Quarterly Journal of Economics, February, 339-76.

Brynjolfsson, Erik, and Lorin Hitt (2003), Computing Productivity: Firm-Level Evidence, Review of Economics and Statistics, 85,4, 793-808.

Berthe, Elizabeth (2006), “An International Focus”, Business Week, August 30, http://www.businessweek.com/bschools/content/aug2006/bs20060830_874480.htm

Best, Michael L., and Colin M. Maclay (2002), Community Internet Access in Rural Areas: Solving the Economic Sustainability Puzzle, Chapter 8 in The Global Information Technology Report 2001-2002: Readiness for the Networked World, ed. Geoffrey Kirkman, Oxford: Oxford University Press.

Census of India (2001), 2001 Census Data, http://www.censusindia.net/results/2001_Census_Data_Release_List.htm (accessed January 8, 2007)

Daveri, Francesco (2000), Is Growth an Information Technology Story in Europe Too? University di Parma and IGIIER working paper, September.

Dewan, Sanjeev and Kenneth L. Kraemer (2000), Information Technology and Productivity: Evidence from Country-Level Data, Management Science, 46, 4, 548-62. 
Internet Kiosks in Rural India: What Influences Success?

Dossani, Rafiq, D.C. Mishra and Roma Jhaveri (2005), Enabling ICT for Rural India, Project Report, Stanford University and National Informatics Centre, India.

Drèze, Jean, and Harris Gazdar (1996), Uttar Pradesh: The Burden of Inertia, in Indian Development: Selected Regional Perspectives, ed. by Jean Drèze and Amartya Sen, Oxford and Delhi: Oxford University Press.

Gordon, Robert J., Does the 'New Economy' Measure Up to the Great Inventions of the Past?, Journal of Economic Perspectives, Fall 2000, 14(4), 49-74.

Grameen Foundation (2006), Village Phone: Connecting Technology and Innovation, http://www.grameenfoundation.org/what_we_do/technology_programs/village_phone/ Green, William (2003), Econometric Analysis $-5^{\text {th }}$ Ed, Saddle River, NJ: Prentice Hall. Hammond, Allen, Digitally Empowered Development, Foreign Affairs, March/April 2001. Indjikian and Siegel (2005), The Impact of Investment in IT on Economic Performance: Implications for Developing Countries, World Development

Intel People and Practices group website (2006), Taking the Internet to the people, http://www.intel.com/research/exploratory/papr/

Kovacs, Gyozo (2000), Telecottages in Hungary, $22^{\text {nd }}$ International Conference: Information Technology Interfaces ITI, Pula, Croatia.

Jhunjhunwala, Ashok (2000), Unleashing Telecom and Internet in India, Paper presented at the Conference on Telecommunications Reform in India, Asia/Pacific Research Center, Stanford University, November 9 \& 10 .

Jorgenson, Dale W., Information Technology and the U.S. Economy, American Economic Review, March 2001, 91(1), 1-32.

Jorgenson, Dale W. (2004), Information Technology and the G7 Economies, August 5 Draft, http://post.economics.harvard.edu/faculty/jorgenson/papers/handbook.extract.2001update080520 04dwj.pdf, accessed September 27, 2004. 
Internet Kiosks in Rural India: What Influences Success?

Kaushik, P.D. and Nirvikar Singh, (2004) Information Technology and Broad-Based

Development: Preliminary Lessons from North India, World Development, 32 (4), pp. 591-607

McNamara, Kerry S. (2003), Information and Communication Technologies, Poverty and

Development: Learning from Experience, Background Paper for the infoDev Annual Symposium, December 9-10, Geneva, Switzerland.

New York Times, Bill Gates Turns Skeptical on Digital Solution’s Scope, November 3, 2000.

OECD (2004), The Economic Impact of ICT: Measurement, Evidence and Implications, OECD: Paris.

Paul, John (2004), What Works: n-Logue’s Rural Connectivity Model - Deploying WirelesslyConnected Internet Kiosks in Villages throughout India, Digital Dividend Study, Washington, DC: World Resources Institute, December.

Planning Commission (2002), National Human Development Report, Government of India: New Delhi.

PROBE team in association with Center for Development Economics (1999), Public Report on Basic Education in India, New Delhi: Oxford University Press.

Reserve Bank of India (2006), Handbook of Statistics on Indian Economy, RBI: Mumbai, India.

Romer, Paul (1994), New Goods, Old Theory, and the Welfare Costs of Trade Restrictions, Journal of Development Economics, 43 (1), 5-38.

Singh, Nirvikar (2004), Information Technology and Rural Development in India, in Integrating the Rural Poor into Markets, in Bibek Debroy and Amir Ullah Khan, eds., New Delhi: Academic Foundation, pp. 221-246

Singh, Nirvikar (2004a), Transaction Costs, Information Technology and Development, UCSC Working Paper, http://econ.ucsc.edu/faculty/boxjenk/wp/Singh_IT_Bardhanconf_Oct04.pdf

Steinberg, James, Information Technology and Development - Beyond 'either/or', Brookings Review, Spring 2003 Vol.21 No.2 pp. 45-48 
Internet Kiosks in Rural India: What Influences Success?

Stiroh, Kevin J. (2002), Information Technology and the U.S. Productivity Revival: What Do the Industry Data Say?, American Economic Review, 92, 5, 1559-1576, December.

Tongia, Rahul, Eswaran Subrahmanian and V.S. Arunachalam (2005), Information and Communications Technologies for Sustainable Development: Defining a Global Research Agenda, Bangalore: Allied Publishers.

World Bank (2002), School Fees: A Roadblock to Education for All, Education Policy Note Series, Washington DC: World Bank

World Bank (2003), India: Sustaining Reform, Reducing Poverty, New Delhi: World Bank and Oxford University Press.

World Bank (2006), India: Inclusive Growth and Service Delivery: Building on India's Success, Development Policy Review, Report No. 34580-IN,, Washington, DC: World Bank.

United Nations (2001), We the peoples: the role of the United Nations in the twenty-first century: the millennium report, New York: United Nations. 
Internet Kiosks in Rural India: What Influences Success?

\section{Appendix}

Table A1 - First Stage Regression Results: N - Logue Internet Kiosks

\begin{tabular}{|c|c|c|}
\hline Total Revenues (LHS) & $\begin{array}{l}\text { Random Effects* - } \\
\text { Baseline Spec. } \\
\text { First Stage results }\end{array}$ & $\mathbf{z}$ \\
\hline Population & 0.0000358 & $(1.070)$ \\
\hline Pop*Town(d) & -0.0000348 & $-(1.040)$ \\
\hline Age & -0.0105292 & $-(0.310)$ \\
\hline Female (d) & 0.6738766 & $(1.500)$ \\
\hline HH Size & 0.2569407 & $(2.240)$ \\
\hline Kiosk Owner (d) & 1.378179 & $(2.650)$ \\
\hline \multicolumn{3}{|l|}{ Education Dummies: } \\
\hline \multicolumn{3}{|l|}{ Some HS (d) } \\
\hline HS (d) & 0.7001664 & $(0.810)$ \\
\hline Some College (d) & 0.659057 & $(0.740)$ \\
\hline Low Caste (d) & -0.229302 & $-(0.410)$ \\
\hline Self Invest & -0.0000305 & $-(2.450)$ \\
\hline Loan Size & -0.0000184 & $-(1.520)$ \\
\hline Monthly Rent & 0.0001574 & $(0.900)$ \\
\hline Kiosk Age & -0.0867934 & $-(2.960)$ \\
\hline \multicolumn{3}{|l|}{ Location Dummies: } \\
\hline Comm Bldg (d) & 0.4644386 & $(0.790)$ \\
\hline Bus Stop (d) & 0.095259 & $(0.170)$ \\
\hline Main Road (d) & 0.8091332 & $(1.430)$ \\
\hline \multicolumn{3}{|l|}{ Residential (d) } \\
\hline Distance HQ & 0.0134687 & $(0.980)$ \\
\hline Distance City & -0.0028189 & $-(0.300)$ \\
\hline Karnataka (d) & 1.239556 & $(1.350)$ \\
\hline Gujrat (d) & -1.017261 & $-(0.850)$ \\
\hline Maharashtra (d) & -0.7239633 & $-(0.980)$ \\
\hline \multicolumn{3}{|l|}{ Instruments: } \\
\hline Browsing Svcs (d) & -1.184415 & $-(4.430)$ \\
\hline Offline Services (d) & -0.3490263 & $-(0.890)$ \\
\hline Test Results (d) & 0.2563924 & $(0.460)$ \\
\hline Education Svcs. (d) & -0.8900884 & $-(3.640)$ \\
\hline DTP (d) & -0.9173647 & $-(3.300)$ \\
\hline Cons & 4.090367 & $(2.100)$ \\
\hline$*(i=73, t=6)$ & $N=438$ & \\
\hline
\end{tabular}

Notes: $(d)=$ dummy variable, bold are significant at $\mathbf{5 \%}$, instruments are jointly significant. 